\title{
The Depersonalized as Vanishing Hero and Heroine in Yorùbá Moral Placards
}

\author{
Olatunde Bayo Lawuyi \\ Department of Archeology and Anthropology \\ University of Ibadan, Nigeria \\ oblawuyi2008@yahoo.com
}

\begin{abstract}
The paper critically examines the relationship between the idea of moral placards and the existence of Yorùbá heroes and heroines. It takes as its starting point the philosophical import of the Yoruba proverb. Ojọ́ a bá kú là ń dère, èèyàn ò sunwọn láàyè (It is on the day one dies that one becomes an idol; no one is appreciated when alive). The paper argues that in the imagination, reality, and social constructions of the Yorùbá, desirable existence would make the dead, and not a living person, a deity, hero or heroine. It further argues that because Yorùbá society permits the co-existence and coextensiveness of individual and public moral placards which is not regarded as an entirely closed system, an otherwise depersonalized person can later become a hero/deity/heroine. Basically, therefore, public moral placard can be revised to accommodate new values, give rise to new class of people, and establish for them an enviable status. These arguments are then deployed to the understanding of the nature of heroes and heroines within the Nigerian post-independence polity.
\end{abstract}

Keywords: Moral placards, Depersonalization, Yorùbá hero/heroine, Omọlúwàbí, Nigeria 
Ėnìàn ko suwọn láàyè, ijọ́a bá kú là ń di ère

You are not good while alive, its when you die that you become a deity

\section{Introduction}

The above Yorùbá proverb constitutes the grounding of our analysis in this paper.The paper argues that in the imagination, reality, and social constructions of the Yorùbá, desirable existence would make a dead person and not the living a deity, hero or heroine. It argues that because Yorùbá society permits the co-existence and coextensiveness of individual and public moral placards, the latter is not an entirely closed system, and so an otherwise depersonalized person can later become a hero/deity/heroine. Basically, public moral placard can be revised to accommodate new values, give rise to new class of people, and establish for them an enviable status.

In light of the experiences and performances of the heroes/heroines we review in this essay iwa, character-not in the ontological sense of existence as has been canvassed by some scholars- (Oyeshile 2003), but rather in the evaluative-experiential sense, signposts the process of self/collective construction and reconstruction of morality in a new direction. Conceptually there is a point in the continuum where the two placards do meet, and complement each other, which could also (or may not be) the point of their disagreement or agreement. This is not up for determination here. The point here is that the construction of the heroine/hero starts from this juncture of agreement or disagreement, particularly the later, to establish the akoni-the daring and brave that overcome physical, social or biological challenges, and the akíkanjú-the one with the never-die spirit.

There are many mind-boggling developments in Yorùbá history, specifically of the historical accounts, mixed with myths, that have produced the knowledge we reckon with as insights into society, culture and development, which sets the scene for the various leitmotifs of the account of the Yorùbá, of who they are and what they do with who they are. In many of the histories of their societies or communities, there were outstanding feats of human courage, and bravery, waged in the midst of all odds against success; there were rejections of personalities that turned up later to be heroes and heroines; and there was desertion that turned to be critique of culture and signs of an extraordinary turn of events. There were also instances of men disappearing into the ground and still being able to project power. Fantasy may mix up with reality in the stories, but, undoubtedly, their inclinations toward the value of moral placard, nationalistic ethos, and localization of meanings for social and cultural "architectures"- as boundary spaces—are never in doubt. It is upon 
this kind of story that the Yorùbá build their communities and nation and reinforce the aesthetic and intellectual plurality subsumed under their shared identity. Are there any implications of this for the Nigeria nation? Yes, in the manner that it can construct its national heroines and heroes.

Specifically, the history of Òwu, one of the earliest Yorùbá kingdoms in the forest belt of today's Nigeria, is that of a war hero and nationalist, Aalúgbuà [the word is spelled in different ways within the Òwu communities], who disappeared into the ground. In İrè Èkìtì, a community in present-day Èkìtì State of Nigeria, Ògún, the Yorùbá warlord and renowned military strategist (reputed also to be the symbol of Yorùbá industrialization), did what Aalúgbuà did-he entered the soil. In İrẹ̀sì, which is a Yorùbá community some kilometers north of Òșogbo, the capital of Ọșun State, Nigeria, Ẹbẹkún, the community founder and his friend Esilẹ, the warlord from the neighboring community of İgbájọ, both "went into the ground," buried as it were, without any assistance. Recounting the number of this kind of incidences across Yorùbáland is not primary to our discourse, nor is their historical commutations our problem. Rather, our problematic is the ideological and moral constitution around the incidences of a form of struggle and rhetoric of images and their rich imports on cultural formation. The struggle concerns the ideology in which the poles of life and death collapse one upon the other, life bringing about death, and death bringing about life, in celebration. And we see reality replaced by, it seems, appearance which is in turn replaced by disappearance, as synecdoche, and as a reductionist style of productions and symbolic game, that Birringer has described as "representation of abstraction that are abstractions of representation, speaking to notions of the self" (1991, 29).

What is argued in our discourse is that what makes the characters that we have identified above heroes is their challenge of the dominant moral placard; and not that the dominant moral placard is not useful, in some regards, but that it needs to be reviewed and reformulated to create a nationalistic spirit. The nationalistic spirit is that of the "dead" metaphorically and not the living. But their promises are for the living. We therefore have the image of a hero spirit trapped in a space which it is unable to comprehend. But that spirit hears its values spoken by the humans that constantly challenge it into performance because they have managed to bring those who are dead alive. The hero spirit comprehends itself in the visibly treacherous, disorderly, and possibly chaotic conditions of humans in which they are powerless to act and where seeing and seeming are discomforting realities.

Ironically, in Yorùbáland the stories of great men and women are predicated on the initial experience of depersonalization, for at one time in their life experiences their individuality was challenged, marginalized, diminished, 
or even slighted. This eventually aroused anger which tilted towards the self-dissolution or death of the self. And this had to take place outside the community, at the periphery of culture and not of society, so that it cannot be drawn, except in limited and well defined circumstances, into the circuitousness of the illusion that sustain the everyday life of community. That illusory life has always, it seems, bothered these heroes, as will be demonstrated in this essay, for this appears to be meaningless, as the signs of people's notion of difference and uniqueness not easily grasped.

Among the Yorùbá, the depersonalized takes up different names, which are not the birth names, but which mark out their violation of moral code and is attributed to a defective self- constitution. The individual can be called alásejù (one prone to the extreme of thoughts and actions), aláșété (one inclined to doing things that would violate public moral code to a point of embarrassment), aláinitijú (the one that has no shame), or even eranko (the one who is animalistic), when doing unimaginable, possibly incomprehensible things outside of cultural dictates. What is clear is that the name-calling is status-demeaning and person-effacing; and to the caller caused by an act in which the self-other relates. It is inscribed by a moral imagination of the ideal. The depersonalization not only calls attention to an ideal that is desirable, but also equally suggests the need for conformity to the ideal, which the self is bound to submit to as a claim of membership in society-probably because there is no room for difference, or for the freedom to operate in a way other than that which fits in a specific domain of moral and social acts.

The labeling or name-calling which will fits most of the Yorùbá heroes and heroines very well can be done by an individual, group, or the entire society. It all depends on where the action takes place, those who witness it, and who is offended. The when could matter too, for it is about what is taken to be odd in the considerations of seeing and seeming that announces new imaginaries and the strategy of symbol destruction, deconstruction, or reconstruction. The ascription is to disallow the circumvention of experience of the sociohistorical world that has been constructed for individual and collective through insistence on regularities or the application to actual, expectable, and historical phenomena grasped from peculiar components of social knowledge that seem to enrich our discourse. A discourse which is that of knowing not how human develop in general, but quite the contrary: how this human, or the state of being, became what it is, and how each of the particulars that ought to be regular did not come to pass and end up specifically as not being there, to support a view, a rationalization, and an objectivity. 


\section{Who Can Be Depersonalized?}

Anyone can be depersonalized; all that is needed is the violation of a moral code. Those who are depersonalized, most likely, must be walking the tight rope of social acceptance-rejection on the one hand, and alienation or incorporation on the other. Although one instance of an act can result in depersonalization, most likely the individual had been walking consistently with historical imagination of a subjectively experienced world. Acceptance of the individual, in spite of a show of difference or the unexpected act means that the individual and not the act can be incorporated into, or can continue, membership in society. This means that the individual can still be made to accept the normative moral code. Rejection, which can be total or partial, signifies tendency towards irreconcilable difference, and it is not only that the act is considered not edifying, it is also assumed to be a threat to the common will, or bond. Alienation would be determined by the perception of the strength of the threat on a continuum which stretches from the serious to the non-serious. Indeed, the name-calling can and does manifests, on a continuum of development process in which the actor is either redeemable or irredeemable. For instance, the evolution of a character understanding can start with aláșejù, alásétẹ, aláinitijú and end as ẹranko, as the irredeemable person to be left in his/her own world of animalistic moral code and/or imaginaries. Two issues emerge at this point: First, character is not a fixed project; it is a process in construction which is space and time bound. Secondly, forms of understanding of character are inherent in a situation, as a space-time bound act, held up to the normative scheme (or the other's moral placard) for meaning and interpretation. Such a moral placard imposes a range of possible cognition and experience within a given culture or action, and as Larsen suggests, "These forms of understanding of schemes of interpretation cannot themselves be the object of experience, but are rather like molds into which all experience is cast" (Larsen 1987, 22). It is from that, in which all experience is cast, the depersonalized, like aláșejù, aláșetẹ, aláinitijú, etc. emerge, the society recognizing that there are shifting experiences that humans encounter, as well as the moral quality of the experience, and moral quality of the agent, redefines the person in varying instances of encounter and action held up to the archetypal model, as the standard gauge.

We can concede that the omolúàbi is that normative moral placard; but would disagree with the view that omolúäbi is either fixed by destiny or by biology, or that it is an imaginary that is left for the individual to compose. Omọlúabí is recommended to each person, as moral code as he/she grapples with the existence dictated by his personhood. According to scholars like Oyeshile, the argument is that: 
Central to all moral and social norms in traditional Yorùbá society is Iwa (character). A person is said to have Iwa, which is used to describe a well-behaved and morally upright person (Omoluabi), or which could be used as a neutral noun with an adjective e.g. Iwa rere (good character) and iwa buburu (bad character) to describe the quality of one's moral conduct (Oyeshile 2003, 84).

The weakness in this view is its purely descriptive orientation, to the discounting of the evaluative aspect of morality. For instance, in order to arrive at the good or bad there must be template of evaluation which, together with the descriptive, subjects action to proper reflection, criticism, and justification. Without the lack of the evaluative criterion or criteria on cause disputation or on a conclusion-how is a decision arrived at?

The bad or good in the character of a person is mere variation on a theme, described as iwà, and there are indeed endless variety of such range of possible cognition on this theme, including iwà ibàjẹ (actions/character that incriminates or destroys), iwà àidára (action/character that is unacceptable or repugnant), and Omolúábí. And as we have noted for the range of names denoting the depersonalized, all these not only contribute to how individuals come into conclusion of the need to depersonalize the actor or actress but also how to understand the concept of naming itself, i.e. does the evaluative comes from the dominant moral placard or the dominant moral placard is a summative, abstract, perspective on behaviors of person or collective? If the latter, it means that as the basis of assessment changes, so too does the moral placard. But if it is the former, then the moral placard would hardly change and everyone is expected to conform to the archetypical type. The former is the position quite often taken in literature on the subject. But the question is: who best represents this archetypical type, and could be a model for reflection and internalization of the appropriate moral standard? I am afraid, there is no such being, since it is an abstract model of the ideal type. Moreover, the issue of the depersonalized comes in, and more so as an ambiguity, when such a person is rejected and later becomes hero from the same point of rejection. This means there can either have been a mistake reading the standard moral code and applying it or, alternatively, the placard is open to new entries.

Our position here is that the issue of omolúabí, as character, can be approached from a statistical paradigm of set and sub-sets, which is itself an attempt to make sense of the verb phrase, "bi" in the coinage omolúabi, which stands for creativity or act of bringing things about. The verb clearly puts the concept, iwà, in the context of evaluative, progressive human relations, and emphasized the individual power to act, positively or negatively in a situation. What can birth $i w a \grave{a}$, as being, and what can iwà birth, as behavior, are two 
faces of the same coin. But as we have seen above, ìwà can bring repugnant or destructive things/acts; and it can be debased; which is how we think Yorùbá actually want to look at the concept, omolúàbí. With them there must be a positive evaluation that is invariably determined by principles of the sub-sets on which the set is based as a descriptive and evaluative notion.

Our study reveals that whoever has $i w a ̀$, in the positive sense, must add value to the social processes of order and development in three significant ways (i) he/she brings in luck or grace, that is Ire (ii) he/she has, or brings, honor, which in Yorùbá is iỳ̀; and, (iii) he/she does not destabilize the equilibrium of social forces, and this means that he/she must exercise iwọntunwọnsi (Lawuyi 1989 and 2010). These sub-sets of the positive ìwà address different aspects of the person's iwà, starting with the birth (eni a bi ire-the one who has the right birth); then the performance that enables him/her to engage standards (omo iyi-child of honor); and finally the dealings with morality and its subsumed honor code e.g. iyiọlá (the honor of civilization), iyiadé (the honor of the crown), etc. which reinforces the social order.

The Yorùbá belief is that the world is made up of the good and bad (ti ibi, ti ire ni a da ilé ayé). Ire, in the aphorism, stresses the good and $i b i$ the bad. And what are those things that are good for a human of character to have? They are owó (money), omọ (children), àlàáfía (peace), orọ (wealth), àikú (longevity). A $i k u$ is taken as the epitome-the father of wealth, but even then it is not as good as having iyi, for as they say, when you are on a journey trying to seek any of the good things of life and you meet honor, you have had it all. So iyi is superior, but even it cannot exist without ire or benevolence. Between the endowments and the public, and the archetypal moral code come the act or action; that is, the performance, which is a term that embraces having a job/ duty, doing the job well, and receiving the appropriate reward, monetarily or symbolically. The recognition of the various iwà attributes, as determinants of the person, goes into the oríki (praise poetry). The individual, for example, can then be described as omo oníran (a child with a pedigree), ọmọ onílé olá (a child from a home of wealth), or omolúábi (a child with a good being).

Simply, Yorùbá postulate an original and ideal universe and then demands that people live in accord with the principles of that universe. But then the path to the archetypical or the standard moral placard, through contemporary situations, is open to a sort of conceptual travel like ire, iyí and orí to give meaning to every encounter. In Odù Ifá Ọyẹ kú Méjì, a line in the Yorùbá divination verses, there was somebody that travelled these paths and led us into a view of character:

Honest people are not up to twenty on earth

The wicked ones number over a thousand and two hundred; 
The days to retaliate are not indefinite

Hence we don't feel seriously embittered;

Divine for the problems facing Akápo

Which are not facing Ifá.

Akápo lacks money

Akápo lacks women

Akápo lacks children

Akápo went to complain to Òrúnmilà

That he desires all the good things of life.

Òrúnmilà directed Akápo to complain to Èșù.

Èșù said all that you desire - Akápo

Do not apply to Ifá

Èșù said, you Akápo

Lodge the complain to your Orí

When Akápo did exactly so

His problems started getting solved

He started dancing

He started rejoicing

He was praising his counselors

The counselors praised Ifa in return

He said it is exactly

What his counselors predicted

Honest people are not up to twenty on earth

The wicked ones number over a thousand and two hundred

The days to retaliate are not indefinite

Hence we don't feel seriously embittered

Divine for the problem facing Akápo

Therefore, all that I desire

I will complain to my Orí

My guiding Orí, let me prosper

You are my counselor (Abimbola 1997, 19).

In the verse of divination, Akápo's situation was held up to the archetypical moral/honor code, which is:

Honest people are not up to twenty on earth

The wicked ones number over a thousand and two hundred

The days to retaliate are not indefinite

Hence we don't feel seriously embittered. 
The verse outlined what could mess up a being - dishonesty, wickedness, revenge and a bitter heart. By keeping to the code, Akápo sustained a character that could get assistance towards the resolution of his problems that was emanating from the lack of the "ire" aspect of his being - money, women, and children. The factor of Ėsù in the poem is to cause Akápo to have a hearty decision, devoid of the "seems like" that generate anxiety. Ėșù, which the Christians mistakenly refer to as Satan, simply brought certainty into uncertain possibilities.

Both ori and ire functioned in the story as causal factors of situational conflict, including situational moral dilemma of choice and interest, as well as the physical wants. Orí allows ire to be; and ire celebrates the orí. This development happens in a process of self-becoming that ultimately leads to the birth of a conformist, conservative, individual adopting historically validated values and standards. The standard moral universe may or may not necessarily enter into a struggle with representation and with the limits of a self or moral field in any obsessive way, but nevertheless it is there for the individual to have, a good existence, "such as is rational to conceive that nature intends that he should have" (Oyeshile 2003, 75). The moral placard itself can be linked to the "moral reasoning involving the supernatural" (ibid), which may be approached rationally or by mentality. Both Orí and Èșù (the god of possibilities) are incorporated into that religious world and in the moral placard serve as ontological predicate of a spiritual-based morality, which introduces the possibility of non-rational or irrational thinking because they can do and undo. Without them there is possibility of failure, for nothing about life is totally rational, at least to the Yorùbá; and irrationality or non- rationality may cause problems of relationships.

A moral placard that inevitably problematizes rational and irrational or non-rational thinking already suggests that there are unlimited type of character to contend with: when humans produce the world of their own making and we have no guarantee that it can be shared with other teams of production; that means there is possibility of rejecting the notion of transcendental morality and so both that of the individual and the society can admit of new moral universes in order to account for reflection, criticism and justification. If morality coincides with each person's moral compass, then that may or may not be rational, that may or may not be spiritual, but who can act independently and yet be seen as having meant well or bad by the society? It is, in this sense, that the Yorùbá moral placard was open to admit the characters of people like Șàngó (god of thunder and lightning), Ògún (god of iron), and the other vanishing heroes and heroines-people who otherwise should have been condemned by the standard moral placard that frowned at their violations of ethical norms of suicide, murder, abuse of power and anger. Șàngó, 
for example, might have been in historical accounts the authoritarian, maximum ruler that Òyó people did not want and thus forced him out of office. He might have been called all kinds of names but he became a deity. Ògún might have, as historical accounts say, killed his people in anger, through what is unbecoming of royalty but he was pronounced a hero. The moral universe of these individuals definitely extended beyond what is good in it for them to have, to the freedom of action and the openness of meaning which allow for what is good in it for "us".

\section{The Vanishing Heroes/Heroines and Moral Placard}

The traditional heroes and heroines in Yorùbá land are likely to be adored because they have such outstanding and awesome presence to be feared and worshipped. They were heroes because they were founders of communities. They survived the travails of being different, which led to the expulsion from their homeland, and or instigated the determination to overcome the odds against them by environmental challenges and human vagaries. They were heroes because in wars of liberation and creation of self-autonomy they expanded the meaning of freedom and what it was to be free. Most likely, they have unusual capabilities, as creative agents, or as one that created the agency for social change, social delivery and cultural transformation. Most likely, in setting themselves apart from a group or a community, they were more violent than diplomatic, hence, their death in wartime or peacetime usually remain a mystery. These happen as way of constructing a larger-than-life image for themselves or for them.

Their extraordinary performance as priests, warrior, hunter, administrator, and/or, creative agents forces the society to create a space for their reckoning in historical consciousness, as they offer for reflection a way of thinking and re-thinking, and of performing that can establish values and morality capable of changing realities of a fundamentally hierarchical order and multiple identities.

Sàngó, as we have mentioned earlier on in this paper, made a difference to the fundamental reckoning of elite as hegemony of common interest and immoral bond. His self-defining, as thunder and lightning, attests to a sense of non-boundedness, of capability of shattering order, of ability to develop and exploit humans in their situations, and of the speed that is needed to cause change that cannot be resisted. But he committed suicide on the outskirt of the community and that is as an outsider that he was to the extant moral placard. Ayélála, among the Ìlàjẹ in Oǹdó State, was a mythical heroine that set up a narrative of a largely and unresolved moral dilemma of crime in a simple, rural society, with the power to affect people spiritually and their actual 
relations by distorting the experienced environment. Dying, still complaining about her innocence of crime credited to her, she disappeared on the outskirt of the community. She would later re-emerge spiritually in the people's fascination with dead power, characterized by a simultaneous "resurrection effect" (Baudrillard 1987, 9), as in a parody of justice.

Èșù, the quintessential public-private operator challenging both spaces into new moral definition of persons and actions, knew that he had to overcome death, to become a hero. He had a fight with Death and was defeated. In Yorùbá mythology, this was a pyrrhic victory for Death, because Òrìsà Ifá interferes and Death was not able to spiritually kill Ėșù. The two deities, linked by the work of divination, overpowered Death (Hallgren 1988, 31). Esu's eventual death is the stuff of hero/heroine making: the challenge of an existing moral order to force inclusiveness that reckons with the self - as a potential actor/actress. The stuff of heroism is created where death can replace life, as life replace death. Both life and death can co-exist and may not destroy each other. In the same vein, art is life and life is art. If art can imitate and reflect life, by the same token, life can imitate art and reflect on it. The point is death is a reflection on life, as life is reflection on death. The mythical hero/heroine represents that hegemony of life and death; it is what you want to see that you see. Their performances as heroes/heroines are usually conflicted with the power of the visible and the shadows of the invisible.

Take the case of Òwu's mythical hero, Aálugbúà, an accomplished personality and indefatigable nationalist who entered into Òwu's cosmogony at death as one who bestrides the universe of ideas and social consciousness as a colossus of unparalleled fame and significant impact on value system. No blame was ever laid on him; but the myth accounting for his deification suggests that he was nevertheless ignored by society; for on a return from a war with the enemy, he was not given the deserving respect, and he walked out of the community and vanished into the ground with a promised to return anytime his people needed his help. Mabogunje and Cooper wrote on this account highlighting the death-life imagery, and the reversal principle that throws dominant moral placard into question:

The story of Asunkungbade's return from the dead appears to be a version of a well-known legend accepted by most of the Owu groups about a dead hero who would return at a time of crisis to save his people. This is more usually attributed to the Orisha Anlugbua than Asunkungbade (Mabogunje and Cooper 1971, 35).

There is a yet unresolvable historical mixed-up of the two personalities called Ańlugbúà (or Aálugbúà) and Asunkúngbadé. In some accounts of 
Òwu's history, Asunkúngbadé was the founder of Òwu Empire and Aálugbúà a mere successful war hero. In other versions both were one and the same person. The mixed-up should not delay us however, as the point being made is that any of them, in the life-death imagery, orchestrated, projected, and represented, as well as actualized, the ideal in the moral universe of the Öwu.

Ordinarily, the Òwu, as valiant warriors, might be less inclined to accepting someone who weeps in order to get a crown as a symbol of their nationalism - the meaning of Asunkúngbadé is one who weeps to get a crown. But they would probably identify with the one whose onomatopoeia name, Aálugbúà, demonstrates a force of strong impact. Asunkúngbadé appears to lack the manly attributes, as an intrepid, though stubborn, individual, but Aálugbúà does not. He, as well, works with the people's fascination with and adoration of a vanishing power. In that power is the universe of meaning which makes sense to the people and to him: the freedom that is distinctive, independent and impactful as the dissolute phenomenon of tradition.

Critical analysis of the vanishing heroes indicates that they are into a moral - building enterprise as the "outsider" uncomfortable with the lack of culture "within" (since they wandered around in the bush they know better; and are not socialized into the unread and speculative in the minds of men). In all cases involving their deaths, they owned up to a sense of responsibility but not of accountability. The latter would have meant that they accept the standard moral code in the society. They were responsible from the viewpoint of their own code of honor, and it is to that code they were accountable.

Ògún, like other vanishing heroes, equally played the insider-outsider game, but ended up in the final account of his experiences as an outsider to a society that appeared strange to him, for they behaved strangely and irresponsibly towards him. There is a narrative about Ògún's depersonalization that bears out our analysis:

Ogun at a time in history settled in this town (Ire) after fighting wars all over the Yorùbá land. But he was approached to fight war for the people of Ondo land. When he was going to fight the war..... he left his son, Ire, to hold brief as traditional head of this town till he would be back. At last Ogun returned home from the war and made to see his family and the Chiefs he left behind. But by that time, the Ire town had become much bigger than he left it. There was a set of prominent Chiefs headed by one Chief Olomodire, they were the council of Chiefs holding meeting about the welfare of the town in those days.

During their meeting, they did not talk but communicated in sign language. It was after their meeting and after they had eaten and drank palm 
wine that they then talked and greeted themselves. So when Ogun finally returned from the war front, he arrived at the place where the Chiefs were already holding their meeting in sign language. He greeted them, but they didn't reply him. He then examined the gourds which they were to use to drink palm wine and found no wine in about three that he checked.

Ogun became angry at this point and unsheathed his sword and began to behead the Chiefs at the meeting. At this critical point of trying to destroy the hegemony of the elite, the Chiefs began to rush out of the venue speaking. So they could speak up! Feeling terribly guilty for his impatience and undoing, Ogun swore never to see his son, Ire. He then turned back to where he was coming from. It was when he was leaving Ire that he met an old man on his way. The old man sensed that he was a warrior and very important person but troubled in his spirit, he then appeased him with a piece of roasted yam and palm wine and succeeded in calming him down.

When Ogun had eaten the yam and taken the palm wine and calmed down, he touched the earth with his sword and made some declarations that he was going to enter into the ground at that spot. He ordered Elepe (the one who appeased him) to go to Ire and continue to appease him there but should never set his eyes on his son, Ire, the same way, he, Ogun, would not be seeing his son again. Ogun also told Elepe to tell his people in Ire to summon him whenever they were to go for war that he would fight for them. Ogun then disappeared into the earth with his crown and weapons at that spot which is called Ijù in İrè-Èkìtì till date (Daily Sun 2014, 29, 34).

What unites the myths of Șàngó with that of Aálugbúà and Ògún is the way(s) they bring to the fore of public discourse the critical moral issues of responsibility, obligation and choice. When Ògún went back to Ire, after the wars in Ondo land, he met a "dead" society where there was no revelry, no voice, no eating and drinking, no exchanges and, therefore, no culture. This, ordinarily, should not have disturbed him as an outsider, but the myth flashed back to the past and passed a judgment on his character: "this was not what he left behind". The value system had changed; the sense of morality had been lost. Obviously, the society, had developed a new moral placard grounded on silence. The Chiefs and the common man were not morally accessible for cross examination and there could be no exchange of shared ethical messages or demands across a barrier of silence, all amounting to patent absurdity, blurring of categories, and mistaken representations. Yet, even outside that community he could found morality, as entreaties, careful reading of personality and needs, provision of food and drinks, and verbal exchanges which Elepe 
symbolizes. What he met in his town was intolerable to him, so there must be a moral reversal, which is in the frame of life and death - life brings death and death brings life.

Ògún preferred to be buried outside the community where he found culture. But even though the outside had culture and life, he still went into the ground. However, he promised to be back on the surface when services are requested. Simply, he was not going to trade his moral placard for that of the society he found inferior, and where he already found a moral placard that corresponds to that of his, he is contented to leave it as it is. In the long run his community recognized the error of holding individuals to the mirror of a placard that is meaningless and crisis prone and was, therefore, willing to change its own. The issues of existence, performance, and morality were examined in this myth and resolved in the narrative. The community moral card, in any case, was eventually opened up to speculations and conjectures.

We may ask, why did Ògún forgive the community? Where did he get the crown that was buried with him at Ijù? Did the old man singularly buried him or we should take it literally that he commanded the ground to open and then close on him? These questions are not trivial; they are pertinent to the conception of power and the unresolved issues in Ògún's own moral placard - based on individuality and life choices. Indeed, the search for goodness that resonates often in the myth of the vanishing heroes brings an unending quest for the self- critical and self-confident person:

Certainly, we may make some rules to live by, but sooner or later we are obliged to scrutinize them with a view of revising them if we want to avoid reverting to a substantively defined concept of morality and defining goodness in terms of our rules of conduct (Larsen 1987, 8).

We found Ògún insisting that the community moral placard be revised, and avoid reverting to one that is not life-changing. We found him insisting that goodness must be in terms of the self and rule of conduct rather than in accordance with a moral placard that was rather too conservative. What he did was to separate intent from action as autonomous spheres in person: The action may be unacceptable, but the intention may be good; the action may be bad but then it might have sprung from bad intention. The challenges of everyday life are trials which are conceivable from the need to choose between, or negotiate the bridge of, life and honor, shame and death, death and honor, life and shame. Every desire of humans to avoid shame initiates a strong tendency towards having honor. But intention is the continuous economy of life and death, honor and shame; it is not just the price that is paid for any of 
them, it is equally the excuse that is offered for not exchanging one for the other.

The last of the outstanding characters to be considered here is Oya, the goddess of river Niger. She, indeed, was the symbol of the feminine side of the patriotic. Oya was initially married to Ògún who, in the myth associating them together, was said to have abused her. She later married Șàngó, the god of thunder and lightning. She was betrayed by Șàngó who leaked her secret as a half-woman - half animal character to a co-wife. The co-wife confronted her with the reality, and in anger she changed to buffalo, her original animal character:

The buffalo went straight for Oya's jealous co-wives and butted them to deaths. She revealed herself to her nine children and told them that she could no longer live among men. She removed the two horns on her head and gave them to her children. She said whenever they needed her help they should strike the two horns together and she would provide assistance. After blessing them, she rubbed her body against theirs. Suddenly, she bolted full speed into the bush and disappeared forever (Isola 2010, 168).

The Ifá corpus, in which the story was told, never mentioned she came back to fulfill her pledge. But that is not the main issue in our consideration. What is significant is the phrase, "that whenever they needed her help... she would provide assistance”, that seems to echo Ògún's own pledge, as well as that of other Yorùbá mythical heroes, to assist the community in providing solution to their problems. She, though depersonalized, was simply acting out of moral code which again is individualistic and which again created the space for her importance in historical consciousness - in-spite of being animalistic.

She had played the insider-outsider game, as heroes do. She had condemned the popular moral placard that society held up as the "truth," as the men considered it right to do. She disappeared to the outside of society, signaling her difference as well as the willingness to be re-incorporated into such a society again, under proper morality. Should the society change, however, she left words with her children: she hinted that she will be willing to accept a sense of responsibility to the society; that is, if they would be willing to recognize and accept her person. Her deification, in our view, indicates that there is no abstract conception of a person's goodness in Yorùbá society; for in the society which can accept an animal-like character for whatever length of time they did, character is reflected in the role played, the statuses assumed, and the challenges confronted. These create the obligatory term in all placards, in 
Oya's and in that of the society. The term iwà is rested on values shared with others that an individual can make a difference to any situation.

\section{Nigeria and the Hero/Heroine Placard}

The consideration of the Yorùbá moral placards done here has enumerated three basics for the emergence of a hero/heroine; namely, 1)The sense of being different from others, internal to the person, in terms of certain categories and possibilities of action( particularly more physical than verbal) that transpire within that notion of difference. The moral is not obvious, because it is not about the special context one happens to be in, although it will still be recognized as special, but it is about what you permit others to see which is inescapable but not too obvious to them. 2) A sense of sacrifice of the self for a cause, which obviously is beyond intentionality, but is placed experientially within the considerations of inside/outside, smooth/rough, access/denial in phenomenological sort of reality-dividing and the absolutizing of Yorùbá title/ status systems. This is the divide the hero/heroine transverse to place him/her in the akonilakíkanjú way of looking at person and situation as though they were the bridge waiting to be crossed by death or life into a total pattern of life for the person and the community. 3) The sense of resurrection effect, which brings the dead alive in the same way that, as Ricoeur $(1979,79)$ would put it, the text frees itself from its mental intention and take its meaning from its ostensive references which, among others, include situation, signs, and symbols, history and historical consciousness and change.

Heroic acts in Nigeria are not ofcourse constructed along the Yorùbá senses and may not have to be. But whatever moral placards justify its existence cannot be immune from change. It is not our desire here to set up the parameters for the change but we can at least consider whether Nigerian heroes and heroines would be, in traditional Yorùbá society, considered such. We examine a few cases.

Historically, Nigerian heroes/heroines, since the inauguration of the nation in 1914, have emerged from political systems as resistance-liberation elements and as state builders, and less as moral canvassers. Obafemi Awolowo, Nnamdi Azikiwe and Herbert Macaulay would belong to the resistance-liberation mode. Awolowo and his Premier colleagues in the First Republic may also be considered as nation builders. However, in our view Chief M. K. O. Abiola and Colonel Adekunle Fajuyi would fall into the category of those we would like to consider as moral canvassers

Most of the resistance-liberation heroes fought the British colonial masters to earn Nigeria's independence. Some did so in their various communities within the post-colonial state, as those who have raised cultural, art 
and political critical discourse in the context of the exigencies of the political economy of which their identity is part. Few in this group, to the best of our knowledge, played up the resurrection effect, or were so portrayed by the public thinking mode. The second group, the state builders, may, in fact, include some of those in the resistance category. However, the defining logic of difference is in the way morality is evoked in the positioning of the self in a heterogeneous cultural space called the nation. Their views and actions in the strategic destruction and reconstruction tap into the unstable, cloudy nature of infrastructure of the national collective body, with their own brand of self-assertiveness evident in material input into the developmental space, their opening up the public space with new demands on performance and selection, and sometimes their putting up new structures of ideas. But even then their moral clout, as moral agents, can hardly be said to be such that act as "pure," self-reflexive signs to nation building. Only a few of them qualifies as having evoked a resurrection effect within the realities of a fundamentally multilingual and deeply divided ethnically conscious nation in such a way that shift previous narratives of self and its historical and moral consciousness to create a space as moral hero/heroine of spectacular beings

Fajuyi and Abiola become very significant if we were to go by the parameters of a self-sacrifice which is beyond intentionality, without the least prospect that the action could be paradigm changing, and could in fact bring about a resurrection effect in an unexpected form. Colonel Adekunle Fajuyi, in the military coup that ousted the regime of General Aguiyi Ironsi, offered the self as a sacrifice in an attempt to save a friend, Ironsi, the military Head of state, and by such save the country. Chief M. K. O Abiola died trying to recover the presidency he won in Nigeria's freest election so far, in 1993, through being poisoned. These are the strongest candidates for Yorùbá heroism achievement. What Abiola did knowing fully well that he could be charged for treason, that he could be killed by state authority, was no doubt a daring action without a clearly ethically considered decision of morality-changing act. And thus far he appears to be the only Nigerian hero that is yearly brought back into life through rituals of public acknowledged sacrifice - though only within the Yorùbá space of the Federation - in ceremonial appreciation of the heroic act the public considered a moral deed.

\section{Conclusion: The Honor Code and the Heroic}

The honor code is precisely the critical issue where two distinct paradigms of morality clash. That clash sets up a I - You correspondence, and any of I or You can be accepted or rejected. In the instances of Ògún's and Oyya life history, there were personal assault on identity and identification, legitimacy and 
opportunism, self-claims and heritage. These were felt as betrayals by the society. The signs of this betrayal were felt in bodily reactions to a situation, as that of a disconnection from people and from society, which will eventually reveal the true character of persons. The myths on the heroes and heroines recognized ability, innate or not, that define status and direct performance credited with honor, as should be the case in a hierarchical society as the Yorùbá where each stratum, each position, has its exclusive moral rules and status - specific expectations and moral excellence. What society does sees in each person is not just the status held, but also the moral expected of that status. When they see the person and not the conformity to the moral code associated with the status, they could remark: "omo ojú ò rí ola rí" "the one that never experienced wealth". When they say, ó jo ara rẹ lójú, he is full of himself, they imply that he is acting the status and not the moral.

Ògún and Oya became hero and heroine respectively, walking the dangerous and treacherous path of shame and honor. What made the difference to the walk towards what one is, or becomes eventually, are activities separating voice and silence, action and inaction, rejection and accommodation, insider and outsider, elite and non-elite. In the path towards shame, Ògún was not the insider he thought he was, just as the billionaire M. K. O. Abiola was not the insider in the military camp he thought he had friends, and the signs defining him otherwise were voice and action that he could not understand. These caused his rejection of society's moral placard. To play their game, he died as one silent and inactive. That opened the door for his readmission into the membership of the society - for they realized it was too painful to bear, and consequently need to change their moral placard.

What counted towards, Ògún's heroism was also noticeable in other case studies, of Aálugbúà, Ayélála, Oya, etc.: the power to vanish and reappear, in which they played the real and the seeming game of life and death. This also parodies justice and right, in which I and you can simultaneously experience "resurrection effect": the magic irrealities of an endless possible-impossible scenario that playfully inhabit the vacant spaces of our mind. The hero or heroine does not think the possible is impossible, he/she plays the transgressive politics, and the anti-aesthetics and anti-normative game of a rebel that announce iyì (honor) against the background of dis-honor; ire (luck/grace) against the background of ill-luck and lack of grace; and action that would be truly liberating against that which is restrictive.

\section{Works Cited}

Abimbola, Wande (1997) Awon Oju Odu Mereerindinlogun. Ibadan: University Press PLC. 
Baudrillard, Jean. Forget Foucault. New York: Semiotext, 1987.

Birringer, J. Theatre, Theory, Post modernism. Bloomington: Indiana University Press, 1991.

Hallgren, Roland. The Good Things in Life: A Study of the Traditional Religious Culture of the Yorùbá People. Loberod: Plus Ultra, 1988.

Isola, Akinwuni. Making Culture Memorable: Essays on Language, Culture and Development Ibadan: Hope Publications Ltd., 2010.

Larsen, Tord (1987), “Action, Morality and Cultural Translation," Journal of Anthropological Research 43(1), 1987: 1-28

Lawuyi, O. B. "Ifa Literature and the Yorùbá Society," African Notes XIII, 1\&2, 1989: 7-13.

Lawuyi, O. B. Ijapa and Igbin: A Discursive Meditation on Politics, Public Culture and Moral Imaginings in Nigeria. Ibadan: University Press PLC, 2010.

Mabogunje, Akin and Cooper, Omer. Owu in Yorùbá History. Ibadan: Ibadan University Press, 1971.

Oyeshile, Olatunji. A. "Traditional Yorùbá Social- Ethical Values and Governance in Modern Africa," Philosophia Africana 6(2), 2003: 81-88.

Ricoeur, Paul. "The Model of the Text: Meaningful Action Considered as a Text," in Paul Rabinow and W. M. Sullivan (eds.), Interpretive Social Science: A Reader. Berkeley: University of California Press, 1979, 73-102. 